\begin{tabular}{ll}
\hline \hline MINING AND METALLURGY INSTITUTE BOR & ISSN: 2334-8836 \\
& UDK: 622 \\
\hline \hline
\end{tabular}

Vladimir Jovanović, ${ }^{*}$ Vladimir Jovanovic ${ }^{* *}$, Marija Jovanovic ${ }^{* * *}$

\title{
FLUE GAS DESULPHURISATION IN SERBIA - TECHNOLOGIES, LEGAL AND ECONOMIC ASPECTS
}

\begin{abstract}
Combustion of coal results in sulfur dioxide $\left(\mathrm{SO}_{2}\right)$ emissions which cause detrimental impacts on the environment and human health. Electric power generating units account for the majority of $\mathrm{SO}_{2}$ emissions in Serbia. Environmental regulations in Serbia require gradual implementation of flue gas treatment technologies for control the emissions of pollutants into the atmosphere. As far as Serbian thermal power plants are concerned, the basic design of systems for flue gas desulphurisation has been developed for two thermal power plants. As wet limestone-based FGD technologies dominate in the world because of high $\mathrm{SO}_{2}$ removal efficiency, cost effectiveness, and gypsum as the by-product, it is expected that Serbian thermal power plants will use this technology. This paper presents a review of commercially available FGD technologies, as well as legal and economic perspective of the process. U.S. EPA's National Risk Management Research Laboratory has published the Coal Utility Environmental Cost Workbook which providesthe rough-order-of-magnitude budgetary cost estimates as the starting point for the limestone forced oxidation cost model that might be a good starting point for cost estimates for Serbian electric utilities.
\end{abstract}

Keywords: flue gas desulfurization, regulations, costs

\section{INTRODUCTION}

Coal provides $40 \%$ of the world electricity needs and it has been the fastestgrowing global energy source since the beginning of the $21^{\text {st }}$ century. Growth in coal use in the last decade has been driven by economic growth of developing economies. Irrespective of economic benefits of coal for those countries, its environmental impact should not be overlooked. Despite positive efforts to retrofit the old plants and decommission the oldest, the least efficient ones, and build more efficient plants, the current state is far from what is needed.

Combustion of coal results in sulfur dioxide $\left(\mathrm{SO}_{2}\right)$ emissions which cause detrimental impacts on the environment -

\footnotetext{
* Law Faculty of Economics and Justice, University Business Academy, Novi Sad, Geri Karolja 1, e-mail:v.jovanovic@itnms.ac.rs

** Institute for Technology of Nuclear and Other Mineral Raw Materials, Belgrade, Franchet D'Eperea 86

${ }^{* * *}$ High School of Professional Studies in Accounting and Stock Exchange Business, Belgrade, Imotska 1
} 
acid deposition in the environment, and human health - aggravation of the existing cardiovascular disease, breathing difficulties, respiratory illness. Electric power generating units account for the majority of $\mathrm{SO}_{2}$ emissions in Serbia. $\mathrm{SO}_{2}$ emissions are vary considerably for different Serbian coal mines, e.g. for lignite from Kosovo mines, they are in the range from around 600 do $1200 \mu \mathrm{g} / \mathrm{m}^{3}$, for lignite from Kolubara mines of around 1800 do $4000 \mu \mathrm{g} / \mathrm{m}^{3}$, and for lignite from Kostolac mines of around 4500 to $8000 \mu \mathrm{g} / \mathrm{m}^{3}$, while $\mathrm{SO}_{2}$ emission limit values for $300 \mathrm{MW}$ plants are $650 \mu \mathrm{g} / \mathrm{m}^{3}$ [1]. Data published by the Environmental protection service of the thermal power plant "Nikola Tesla" show that emissions from that plant exceed emission limit values set by regulations by three to four times [2].

Since the 1970`s, various policy and regulatory measures have created a growing commercial market for clean coal technologies, with the result that their costs have fallen and performance has improved. Undoubtedly, the air quality will continue to improve in the future because of the improved technology.

Environmental regulations, introduced in Serbia in the past decade, require gradual implementation of flue gas treatment technologies for controlling the emissions of pollutants into the atmosphere. As far as Serbian thermal power plants are concerned, the basic design of systems for flue gas desulfurization (FGD) have been developed for the thermal power plants "Nikola Tesla" A and "Kostolac" [3].
This paper presents a review of commercially available FGD technologies, as well as legal and economic perspective of the process of flue gas desulfurization in Serbia.

\section{CLASSIFICATION OF FLUE GAS DESULPHURISATION TECHNOLOGIES}

There are various technologies for removal of $\mathrm{SO}_{2}$ from flue gas produced by thermal power plants, and some of them have tens of thousands of hours of operational experience. This paper considers commercially available FGD technologies with reliable performance and sufficient quality and quantity of data.

Commercially available FGD technologies can be classified as non-regenerative and regenerative, depending on treatment of sorbent after sorption of $\mathrm{SO}_{2}$. In the nonregenerative technologies, $\mathrm{SO}_{2}$ is permanently bound by the sorbent, which is utilized as by-product (e.g., gypsum), or disposed of as a waste. In regenerative technologies, during regeneration process, $\mathrm{t}$ $\mathrm{SO}_{2}$ is released from sorbent and may be further processed to provide liquid $\mathrm{SO}_{2}$, sulfuric acid or elemental sulfur. Both technologies can be further classified as wet or dry. Wet slurry waste or by-product is produced in wet processes, and flue gas leaves the absorber saturated with moisture. In dry processes, dry waste material is produced and flue gas leaving the absorber is not saturated with moisture. The "conventional" classification of FGD processes is shown in Table 1. 
Table1 Classification of FGD processes

\begin{tabular}{|c|c|c|c|}
\hline \multicolumn{4}{|c|}{ Flue gas desulfurization } \\
\hline \multicolumn{2}{|c|}{ Non-regenerative } & \multicolumn{2}{|c|}{ Regenerative } \\
\hline Wet & Dry & Wet & Dry \\
\hline $\begin{array}{l}\text { Limestone forced } \\
\text { oxidation }\end{array}$ & Lime spray drying & Sodium sulfate & \multirow{5}{*}{$\begin{array}{l}\text { Activated } \\
\text { carbon }\end{array}$} \\
\hline $\begin{array}{l}\text { Limestone inhibited } \\
\text { oxidation }\end{array}$ & Duct sorbent injection & Magnesium oxide & \\
\hline Lime & Furnace sorbent injection & Sodium carbonate & \\
\hline $\begin{array}{l}\text { Magnesium-enhanced } \\
\text { lime }\end{array}$ & \multirow[t]{2}{*}{ Circulating fluidized bed } & \multirow[t]{2}{*}{ Amine } & \\
\hline Seawater & & & \\
\hline
\end{tabular}

According to the information of the International Energy Agency's Coal Research Center in London, England provided in CoalPower3 Database regenerative FGD processes are used only marginally, while the non-regenerative FGD processes are most frequently applied. In this paper, FGD technologies are grouped into the following three major categories: nonregenerative wet FGD, non-regenerative dry FGD and wet and dry regenerative FGD. This grouping of FGD technologies is consistent with other economic evaluations of FGD [4].

\section{Non-regenerative Technologies}

In non-regenerative wet FGD processes, the flue gas reacts with alkaline limestone slurry in a spray tower or tray tower absorber, most often counterflow vertically oriented spray tower. Limestone slurry is prepared in two steps. The first, limestone is crushed into fine powder of desired particle size distribution, and after that it is mixed with water in a slurry preparation tank. Sorbent slurry is then pumped into the absorber reaction tank. In a counterflow tower, the flue gas flows upwards, while limestone slurry is sprayed downwards by an array of spray nozzles. $\mathrm{SO}_{2}$ is removed in the absorber by sorption and reaction with the slurry. These reactions are completed in a reaction tank, in which finely ground limestone particles dissolve and react with dissolved $\mathrm{SO}_{2}$.

In order to improve reliability of system, the majority of non-regenerative wet FGD applications require control of oxidation, so limestone forced oxidation process (LSFO) has become the preferred technology worldwide. Limestone inhibited oxidation process is particularly well suited for applications with high sulfur coals (LSIO).

Hydrated calcitic lime slurry in the lime process is more reactive than limestone slurry, but is more expensive. Magnesiumenhanced lime process (MEL) is a variation of the lime process in which lime is magnesium-enhanced (usually 5-8 \% magnesium oxide). Magnesium salts are more soluble compared to calcitic sorbents and scrubbing liquor; dolomitic lime is more alkaline (usually $20 \%$ magnesium oxide). Due to the increased alkalinity and solubility, $\mathrm{pH}$ value is usually in the range of 6.0 
to 7.0. The lime process benefits from the alkalinity of fly ash, too. The efficiency of MEL is higher in much smaller absorbers than limestone scrubbers, which enables a considerable decrease of liquid-to-gas ratio.

In the seawater process, the natural alkalinity of seawater neutralizes $\mathrm{SO}_{2}$. The seawater chemical process is similar to the LSFO. The seawater is discharged into the ocean after scrubbing, so the evaluations of local conditions and construction materials with increased corrosion resistance are reqired for this process due to high concentrations of chloride.

In dry FGD technologies, $\mathrm{SO}_{2}$-containing flue gas contacts alkaline sorbent, most often lime, which produces dry waste with properties similar to fly ash. The sorbent can be in an aqueous slurry form or as a dry powder. Absorber vessels for reaction of sorbent with $\mathrm{SO}_{2}$ are necessary in the lime spray drying and circulating fluidized bed processes, while in duct sorbent injection process and furnace sorbent injection processes, only sorbent delivery equipment is required. In these processes, sorbent recirculation increases their utilization.

Lime Spray Drying (LSD) is rarely used for high sulfur content coals and the sorbent in it is in aqueous slurry form.

In the Duct Sorbent Injection (DSI) process, finely dispersed sorbent, hydrated lime or sodium bicarbonate, contact with the flue gas in the flue gas duct between the air preheater and particulate control device. The amount of hardware is minimized.

In the Furnace Sorbent Injection (FSI), a dry sorbent is injected into the furnace in toptimum temperature region above the flame.

In the Circulating Fluidized Bed (CFB), a dry sorbent, most often $\mathrm{Ca}(\mathrm{OH})_{2}$, contacts with humidified flue gas, which flows upward through a bed of sorbent solids to a particulate control device. Some of its catch is recirculated in order to increase the utilization of sorbent. An additional benefit of this process is continuous abrasion of sorbent particles, which results in the exposure to fresh alkali.

\section{Regenerative FGD Technologies}

Regenerative FGD technologies include four wet regenerative processes in which sodium sulfite, magnesium oxide, sodium carbonate, and amine are in contact with flue gas, and one dry regenerable process with the use of activated carbon. These processes are characterized by their product, a concentrated stream of $\mathrm{SO}_{2}$. Regenerative FGD technology is only marginally used throughout the world. These processes have comparatively high operating labor costs relative to the other FGD processes. Product marketability may be the major problem. As the result, some of the existing regenerable FGD-technology-equipped units have been converted to advanced limestone wet FGD.

\section{Previous Application of Procedures for Flue Gas Desulphurisation}

In 1980, approximately 30,000 MWe FGD capacity was installed and this trend was increased at approximate rate of 100,000 MWe per decade [5]. There was no significant increase in regenerable FGD capacity since the early ' 80 s. Since the wet FGD technology has dominated so far, an analysis of wet FGD processes application is interesting. The majority of FGD technology applications worldwide make wet limestone and spray drying processes. In wet FGD technologies, which do not use wet limestone, the lime as more expensive sorbent is 
used, or they are limited by the availability of sorbent required by the process. Dry FGD technologies, apart from LSD, have not had sufficient commercial experience or offer limited sorbent utilization.

Wet FGD technologies predominate over other technologies because of high $\mathrm{SO}_{2}$ removal efficiency coupled with cost effectiveness, particularly wet-limestonebased technologies. Gypsum, as byproduct, has increased the attractiveness of wet FGD technologies. Limited utilization of dry FGD technologies resulted from higher reagent cost and limitations regarding by-product disposal.

Forced limestone once through wet process is most widely used wet scrubbing system in the world today, comprising around one third of the wet scrubbing systems. Forced oxidation is preferred process because it reduces the scaling potential within the scrubber, enhances dewatering capability, and produces abyproduct suitable for either landfill or sale as gypsum for agriculture and cement industry. Enhanced dewatering capability additionally reduces the waste disposal area requirement.

\section{LEGAL ASPECT OF FLUE GAS DESULPHURISATION IN SERBIA}

Environmental protection legislation, particularly THE Directive 2010/75/EU of the European Parliament and Council of 24 November 2010 on industrial emissions (integrated pollution prevention and control) [6] sets stringent operating conditions, technical requirements and emission limit values (ELV) for plants for $\mathrm{SO}_{2}$ at 200 $\mathrm{mg} / \mathrm{m}^{3}$. Such regulations require a detailed analysis of the coal quality, as well as careful selection of flue gas desulphurisation technology and cost estimation.
One of the main goals of the National Environmental Protection Program of the Republic of Serbia from 2005 to 2014 in the energy sector, is reduction the emission of sulfur oxides from the thermal power plants, such as the Thermal Power Plant "Kostolac B" and Thermal Power Plant "Nikola Tesla A" and "Nikola Tesla B". So far, onlythe electro filters have been installed for removal of particulate matter in these plants, but no measures have been implemented for flue gas desulfurization.

As wet limestone-based FGD technologies dominate in the world because of high $\mathrm{SO}_{2}$ removal efficiency, cost effectiveness, and gypsum as by-product, it could be expected that the Serbian thermal power plants will use this technology and two companies, Hitachi, Mitsubishi, have presented their technologies for FGD in the wet limestone process with commercial gypsum production at the First Symposium "On Flue Gas Desulphurisation", held in Palić in 2012. [7, 8].

The Ministry of Education, Science and Technological Development of the Republic of Serbia has funded the Project "Development of Technological Processes for Obtaining of Ecological Materials Based on Nonmetallic Minerals" and within it some investigations of lithotamnian limestone from the "Dobrilovići" deposit near Loznica for use in non-regenerative wet process. These investigations proved that this limestone is suitable for flue gas desulphurisation and provides gypsum as by-product of the process with satisfying quality [9].

In the past two decades, the capital costs for $\mathrm{SO}_{2}$ scrubbers have decreased by over $30 \%$ and are reported to be approximately \$ $100 / \mathrm{kW}$ [10]. Retrofit of scrubbers on the 
existing units increases the capital cost up to $30 \%$ depending on modifications of the existing equipment and conditions under which the units operate, such as flow rate and temperature. Costs also increase with the increase of sulfur content since the same volume of gas must be treated with more reagent. Limestone and lime as reagents are not expensive themselves, but the use of additives or reagent enhancers significantly increases costs. Costs are also affected by waste product disposal costs, by-product saleable prices, as well as by loss of required energy and other fixed and variable costs [5]. Control efficiencies for limestone systems are limited to approximately $90 \%$, while control efficiencies of lime is up to $95 \%$, but it is significantly more costly.

\section{ESTIMATION OF FLUE GAS DESULPHURISATION COSTS}

Continuous Emission Measurement often does not provide data of the required accuracy for FGD retrofit design, so the additional data have to be calculated based on coal analysis and the existing boiler data which are individually measured [11]. Coal quality analysis provides essential input data for flue gas desulphurisation plant design reference coal quality, flue gas analysis at the inlet of the plant, as well as the range of $\mathrm{SO}_{2}$ concentrations in flue gas [12].

Flue gas desulphurisation process does not involve only system of flue gas and absorber, but also associated systems for sorbent preparation and by-product management. The basic parameters, used for designing of FGD systems, are work parameters of plants (such as its power, specific heat consumption, excess air, flue gas temperature), flue gas characteristics (volume flow, moisture, concentration of chlorides and fluorides, particulate matter and $\mathrm{SO}_{2}$ ), allowed content of particulate matter in the emitted flue gas, required byproduct quality. Technical and economic analyses of the possibility of application the flue gas desulphurisation processes in the Serbian power plants showed that wet limestone forced oxidation process is the best solution.

The additional elements that should be considered are space around the power plant, investments, the time power plant has to be stopped for during the installation of FGD system, plans for operation of power plant during the year.

Gypsum as by-product of desulphurisation process requires to be disposed at non-hazardous waste disposal landfill where no biodegradable waste is disposed, and the disposal landfill must fulfill the necessary conditions for preventing soil, air and surface water pollution by combination of geological barriers and impermeable layers [13].

\section{CONCLUSION}

Coal burning in the electricity generation accounts for the greatest share of sulfur dioxide emissions in Serbia. The environ-mental regulations, which have been adopted in Serbia in the past decade, require gradual introduction of technologies for flue gas treatment, while one of the basic goals of the National Program for Environmental. Protection of the Republic of Serbia 2005-2014 in the energy industry is decreasing the sulfur dioxide emissions from the thermal power plants. 
So far, in the thermal power plants, no measures have been taken for flue gas desulphurisation. As limestone based flue gas technologies dominate in the world due to high efficiency, cost-efficiency and gypsum as by-product, it can be expected that the Serbian thermal power plants would use this technology. Technical and economic analyses of the possibility of application the flue gas desulphurisation technologies in the thermal power plants in Serbia have shown that the LSFO technology is the best solution.

The Air Pollution Prevention and Control Division of U.S. EPA's National

Risk Management Research Laboratory has published the Coal Utility Environmental Cost Workbook (CUECost) [14]. CUECost provides rough-order-of-magnitude budgetary cost estimates $( \pm 30 \%$ accuracy) for between 100 and $2000 \mathrm{MWe}$ net LSFO application based on the userdefined design and economic criteria. CUECost algorithms provide the starting point for the LSFO cost model that might be a good starting point for cost estimates for the Serbian electric utilities.

\section{REFERENCES}

[1] Decree on Limit Values of Pollutant Emission into Air, Official Gazette of the Republic of Serbia 71/201 i $6 / 2011$.

[2] http://kgh.kvartetv.com/fajlovi/ 37.\%20kongres/37-38.pdf

[3] Mitrović D, Kostović N, Milovanović $Đ$, Some specific design aspects of integration flue gas desulfurization plants at existing lignite fired thermal power stations in Serbia, Proceedings of the First symposium "On Flue Gas

Desulfurization", Chamber of Commerce and Industry of Serbia, (2012) 12-19.

[4] Keeth RJ, Ireland PA, and Radcliffe PT, Economic Evaluations of 28 FGD Processes, in Proceedings of the 1991 $\mathrm{SO}_{2}$ Control Symposium Palo Alto CA, Electric Power Research Institute, 1991, 273-2-90.

[5] http://www.ieacoal.org.uk/site/2010/databasesection/coal-power?LanguageId $=0$

[6] http://eur-lex.europa.eu/LexUriServ/ LexUriServ.do?uri=OJ:L:2010:334:00 17:0119:en:PDF.

[7] Okamoto T, Nagayasu T, Tanaka N, Mitsubiši wet flue gas desulfurization technology, Proceedings of the First symposium "On Flue Gas Desulfurization", Chamber of Commerce and Industry of Serbia, (2012) 60-71.

[8] Taguchi Y, Vollmer B, Hitachi flue gas desulfurization technology, Proceedings of the First symposium "On Flue Gas Desulfurization", Chamber of Commerce and Industry of Serbia, (2012), 27-34.

[9] Sekulić Ž, Jovanović V, Kašić V, Lithotamian limestone from the deposit "Dobrilovići" in flue gas desulfurization by wet process, Mining Engineering, 3 (2012) 41-48.

[10] Smith D, Cost of SO2 scrubbers down to $\$ 100 / \mathrm{kW}$, Power Engineering, 105 (2001) 63-66.

[11] Thomsen R, Dickamp M, FGD design criteria, Proceedings of the First symposium "On Flue Gas Desulfuri- 
zation", Chamber of Commerce and Industry of Serbia, (2012) 20-26.

[12] Stojiljković D, Životić D, Milovanović D, Jovović A, Manić N, Jovanović V, The importance of defining the reference coal characteristics for designing FGD systems, Proceedings of the First symposium "On Flue Gas Desulfurization", Chamber of Commerce and Industry of Serbia (2012) 2-11.
[13] Vlajić D, Simović I, Kostović N, Stanković M, Disposal sites of TPP Kostolac B3 block flue gas desulfurization gypsum suspension, Proceedings of the First symposium "On Flue Gas Desulfurization“, Chamber of Commerce and Industry of Serbia (2012) 155-162.

[14] http://www.epa.gov/ttncatc1/ products.html\#cccinfo 


\begin{tabular}{ll}
\hline \hline INSTITUT ZA RUDARSTVO I METALURGIJU BOR & ISSN: 2334-8836 \\
& UDK: 622 \\
\hline \hline
\end{tabular}

Vladimir Jovanović, ${ }^{*}$ Vladimir Jovanovic ${ }^{* *}$, Marija Jovanovic ${ }^{* * *}$

\section{ODSUMPORAVANJE DIMNIH GASOVA U SRBIJI - TEHNOLOŠKI POSTUPCI, PRAVNI I EKONOMSKI ASPEKTI}

Izvod

Sagorevanjem uglja emituje se sumpor-dioksid $\left(\mathrm{SO}_{2}\right)$, koji štetno utiče na životnu sredinu i zdravlje ljudi. Postrojenja za proizvodnju električne energije emituju najveći deo sumpor-dioksida u Srbiji. Propisi iz oblasti zaštite životne sredine u Srbiji nalažu postepenu implementaciju tehnologija za tretman dimnih gasova, odnosno kontrolu emisija zagađivača u atmosferu. Što se termoelektrana u Srbiji tiče, pripremljeni su idejni projekti za odsumporavanje dimnih gasova za dve termoelektrane. Kako u svetu dominira primena tehnoloških postupaka za odsumporavanje dimnih gasova zasnovanih na mokrim postupcima zbog visoke efikasnosti u otklanjanju $\mathrm{SO}_{2}$, ekonomske isplativosti $i$ dobijanja gipsa kao nusproizvoda, može se očekivati da će se ovaj postupak primenjivati i u termoelektranama u Srbiji. Ovaj rad predstavlja pregled tehnoloških postupaka za odsumporavanje dimnih gasova, kao i pravne $i$ ekonomske aspekte postupaka. Laboratorija za istraživanje upravljanja rizicima američke Agencije za zaštitu životne sredine objavila je model za izračunavanje troškova zaštite životne sredine kod upotrebe uglja. Ovaj model daje okvirnu procenu troškova koja može služiti kao polazna osnova za procenu troškova odsumporavanja dimnih gasova u termoelektranama u Srbiji.

Ključne reči: sagorevanje uglja, odsumporavanje dimnih gasova, propisi, troškovi

\section{UVOD}

Sagorevanjem uglja obezbeđuje se $40 \%$ potreba za električnom energijom u svetu, a ugalj predstavlja globalni izvor enegrije sa najvećim rastom potrošnje od početka ovog veka. Porast potrošnje uglja u poslednjoj deceniji podstaknut je ekonomskim razvojem zemalja u razvoju. Bez obzira na ekonomsku korist od uglja koje te zemlje imaju, ne sme se prevideti njegov uticaj na životnu sredinu. Uprkos naporima da se stara postrojenja tehnološki unaprede i da se najstarija (najmanje efikasna) izbace iz upotrebe, te da se izgrade termoelektrane sa odsumporavanjem dimnih gasova, trenutno stanje u ovoj oblasti je daleko od zadovoljavajućeg.

Sagorevanje uglja dovodi do emisije sumpor-dioksida $\left(\mathrm{SO}_{2}\right)$, koji ima štetne posledice po životnu sredinu (acidifikacija životne sredine) i po ljudsko zdravlje

\footnotetext{
* Pravni fakultet za privredu i pravosuđe, Univerzitet Privredna akademija, Novi Sad, Geri Karolja 1, e-mail:vladimir.marija.jovanovic@gmail.com

** Institut za tehnologiju nuklearnih i drugih mineralnih sirovina, Beograd, Franše D'Eperea 86

**** Visoka škola strukovnih studija za računovodstvo i berzansko poslovanje, Beograd, Imotska 1
} 
(pogoršanje postojećih kardiovaskularnih oboljenja, teškoće sa disanjem, respiratorna oboljenja). Postrojenja za proizvodnju električne energije odgovorna su za najveći deo emisija $\mathrm{SO}_{2}$ u Srbiji. Koncentracije $\mathrm{SO}_{2}$ se bitno se razlikuju kod lignita iz pojedinih ugljenih basena. U slučaju lignita Kosovskog basena su od 600 do $1200 \mu \mathrm{g} / \mathrm{m}^{3}$, kod lignita Kolubarskog basena od oko 1800 do $4000 \mu \mathrm{g} / \mathrm{m}^{3}$, kod lignita Kostolačkog basena od 4500 do $8000 \mu \mathrm{g} / \mathrm{m}^{3}$. Granična vrednost emisije $\mathrm{SO}_{2}$ za ložišta toplotne snage veće od $300 \mathrm{MW}$ iznosi $650 \mu \mathrm{g} / \mathrm{m}^{3}$ [1]. Prema podacima kojima raspolaže Služba za zaštitu životne sredine JP TENT, emisija $\mathrm{SO}_{2}$ iz Termoelektrane „Nikola Tesla“ je tri do četiri puta veća od GVE koju propisuje naša Uredba $\left(650 \mu \mathrm{g} / \mathrm{m}^{3}\right)$ [2].

Od sedamdesetih godina prošlog veka različite regulatorne mere stvorile su komercijalno tržište za tehnologije čistog sagorevanja uglja koje sve više raste, što za posledicu ima smanjenje troškova postupaka i unapređenje njihovih performansi. Nesumnjivo je da će kvalitet vazduha u budućnosti biti sve bolji zbog primene unapređenih tehnologija.

Propisi u oblasti zaštite životne sredine koji su usvojeni u Srbiji u protekloj deceniji zahtevaju postepeno uvođenje tehnologija za tretman dimnih gasova radi kontrole emisija zagađivača $u$ atmosferu. Što se tiče termoelektrana u Srbiji, izrađeni su idejni projekti za odsumporavanje dimnih gasova (ODG) za termoelektrane „Nikola Tesla“ A i „Kostolac“ [3].

Ovaj rad daje pregled komercijalno dostupnih tehnoloških postupaka za ODG, kao i pravnu i ekonomsku perspektivu problema odsumporavanja dimnih gasova $u$ Srbiji.

\section{KLASIFIKACIJA TEHNOLOŠKIH POSTUPAKA ZA ODSUMPORA- VANJE DIMNIH GASOVA}

Postoje različiti tehnološki postupci za uklanjanje $\mathrm{SO}_{2}$ iz dimnih gasova koji proizvode termoelektrane, a neke od njih se primenjuju već više desetiha hiljada časova. Ovaj rad bavi se komercijalno dostupnim tehnološkim postupcima za ODG sa pouzdanim performansama i dovoljnom količinom pouzdanih podataka.

Komercijalno dostupni tehnološki postupci za ODG mogu se klasifikovati na neregenerativne $\mathrm{i}$ regenerativne zavisno od tretmana sorbenta nakon sorpcije $\mathrm{SO}_{2}$. Kod neregenerativnih tehnoloških postupaka, $\mathrm{SO}_{2}$ se trajno vezuje za sorbent koji se koristi kao nusproizvod (npr. gips), ili predstavlja otpadni materijal. Kod regenerativnih tehnoloških postupaka, tokom postupka se $\mathrm{SO}_{2}$ izdvaja od sorbenta i može se dalje obrađivati kako bi se dobio tečni $\mathrm{SO}_{2}$, sumporna kiselina ili elementarni sumpor. Oba tehnološka postupka se mogu dalje klasifikovati na „mokre“ i ,suve“ postupke. Vlažan mulj kao otpad ili nusproizvod se dobija mokrim postupkom, a dimni gas izlazi iz apsorbera zasićen vodom. U suvom postupku dobija se suvi otpad, a dimni gas koji izlazi iz apsorbera nije zasićen vodom. „Tradicionalna“ klasifikacija postupaka za ODG prikazana je u Tabeli 1. 
Tabela 1. Klasifikacija tehnoloških postupaka za ODG

\begin{tabular}{|c|c|c|c|}
\hline \multicolumn{4}{|c|}{ Odsumporavanje dimnih gasova } \\
\hline \multicolumn{2}{|c|}{ Neregenerativni } & \multicolumn{2}{|c|}{ Regenerativni } \\
\hline Mokri & Suvi & Mokri & Suvi \\
\hline $\begin{array}{l}\text { Odsumporavanje sa krečnjakom } \\
\text { ubrzanom oksidacijom }\end{array}$ & $\begin{array}{l}\text { Suvi postupak sa } \\
\text { raspršivanjem }\end{array}$ & $\begin{array}{l}\text { Odsumporavanje sa } \\
\text { natrijum sulfatom }\end{array}$ & \multirow{5}{*}{$\begin{array}{l}\text { Odsum- } \\
\text { poravanje } \\
\text { sa } \\
\text { aktivnim } \\
\text { ugljem }\end{array}$} \\
\hline $\begin{array}{l}\text { Odsumporavanje sa krečnjakom } \\
\text { prekinutom oksidacijom }\end{array}$ & $\begin{array}{l}\text { Ubacivanje sorbenta } \\
\text { u dimni kanal }\end{array}$ & $\begin{array}{l}\text { Odsumporavanje sa } \\
\text { magnezijum oksidom }\end{array}$ & \\
\hline Odsumporavanje sa krečom & $\begin{array}{l}\text { Direktno ubacivanje } \\
\text { sorbenta u ložište }\end{array}$ & $\begin{array}{l}\text { Odsumporavanje sa } \\
\text { natrijum karbonatom }\end{array}$ & \\
\hline $\begin{array}{l}\text { Odsumporavanje sa magneziju- } \\
\text { mom obogaćenim krečom }\end{array}$ & \multirow{2}{*}{$\begin{array}{l}\text { Odsumporavanje u } \\
\text { fluidizovanom sloju }\end{array}$} & \multirow{2}{*}{$\begin{array}{l}\text { Odsumporavanje } \\
\text { aminima }\end{array}$} & \\
\hline $\begin{array}{l}\text { Odsumporavanje sa morskom } \\
\text { vodom }\end{array}$ & & & \\
\hline
\end{tabular}

Prema informacijama Centra za istraživanje uglja Međunarodne agencije za energiju iz Londona datim u bazi podataka CoalPower3, regenerativni postupci ODG koriste se retko, dok se najčešće koriste neregenerativni postupci za ODG. U ovom radu tehnološki postupci za ODG su grupisani u tri osnovne kategorije: neregenerativni mokrim postpukom, neregenerativni suvim postupkom i regenerativni tehnološki postupci za ODG suvim postupkom. Ovakva podela tehnoloških postupaka za ODG je u skladu sa procenama troškova ODG [4].

\section{Neregenerativni tehnološki postupci}

Kod neregenerativnih tehnoloških postupaka za ODG dimni gas reaguje sa alkalnom krečnjačkom suspenzijom u ložištu ili u dimnom kanalu, najčešće u toranjskom suprotno strujnom apsorberu. Krečnjačka suspenzija se priprema u dve faze. Najpre se krečnjak melje u fini prah, nakon čega se meša sa vodom u rezervoaru za pripremu suspenzije. Suspenzija sorbenta se zatim raspršuje u rezervoar za reakciju apsorbera.
U toranjskim suprotnostrujnim apsorberima dimni gas se kreće naviše, dok se krečnajčka suspenzija raspršuje naniže pomoću mnoštva mlaznica. $\mathrm{SO}_{2}$ se uklanja u apsorberu sorpcijom i reakcijom sa suspenzijom. Ove reakcije se dovršavaju u reakcionom bazenu, u kome se fino mlevene čestice krečnjaka rastvaraju da bi reagovale sa rastvorenim $\mathrm{SO}_{2}$.

Kako bi se unapredila pouzdanost sistema, kod većine mokrih neregenerativnih postupaka za ODG potrebna je kontrola oksidacije, tako da je odsumporavanje sa krečnjačkom ubrzanom oksidacijom postalo tehnološki postupak izbora širom sveta. Odsumporavanje sa krečnjakom prekinutom oksidacijom je naročito pogodno za ugalj sa visokim sadržajem sumpora.

Hidrirana krečna kalcitna suspenzija $\mathrm{u}$ krečnom postupku je reaktivnija od krečnjačke suspenzije, ali je tehnološki postupak skuplji. Postupak sa krečom obogaćenim magnezijumom predstavlja varijaciju krečnog postupka u kome se kreč obogaćuje magnezijumom (obično 5-8 procentnim magnezijum okisdom). Magnezijumove soli su rastvorljivije u poređenju sa kalcitnim 
sorbentima, a tečnost za ispiranje, dolomitski kreč, je alkalnija (obično dvadesetoprocentni magnezijum oksid). Zbog povećane alkalnosti i rastvorljivosti, $\mathrm{pH}$ vrednost je obično u rasponu od 6,0 do 7,0. Postupak sa krečom je uspešniji i zbog alkalnosti letećeg pepela. Efikasnost odsumporavanja magnezijumom obogaćenim krečom je veća $u$ znatno manjim apsorberima od krečnjačkih postrojenja za prečišćavanje, što omogućuje značajno smanjenje koeficijenta gastečnost.

U postupku sa morskom vodom prirodna alkalnost morske vode neutralizuje $\mathrm{SO}_{2}$. Hemijski proces sa morskom vodom je sličan krečnjačkom postupku sa ubrzanom oksidacijom. Morska voda se ispušta u okean nakon prečišćavanja, tako da su za ovaj postupak neophodni procena lokalnih uslova i građevinski materijali sa pojačanom otpornošću na koroziju zbog visokih koncentracija hlorida.

U suvim postupcima za ODG dimni gas koji sadrži $\mathrm{SO}_{2}$ reaguje sa alkalnim sorbentom, najčešće krečom, te $u$ toj reakciji nastaje suvi otpad koji ima karakteristike slične letećem pepelu. Sorbent može biti tečna suspenzija ili suvi prah. Delovi apsorbera u kojima dolazi do reakcije sorbenta sa $\mathrm{SO}_{2}$ su neophodni $\mathrm{u}$ suvom sistemu sa raspršivanjem i sistemu sa cirkulišućim fluidizovanim slojem, dok je kod ubacivanja sorbenta u dimni kanal i direktnog ubacivanja sorbenta u ložište potrebna samo oprema za dopremanje sorbenta. U ovim postupcima recirkulacija sorbenata povećeva njihovo iskorišćenje.

Suvi postupak sa raspršivanjem se retko koristi za ugalj sa visokim sadržajem sumpora, a sorbent u ovom postupku je u tečnom stanju.

$\mathrm{U}$ postupku ubacivanja sorbenta $\mathrm{u}$ dimni kanal fino raspršeni sorbent, hidrirani kreč ili natrijum hidrogenkarbonat, reaguje sa dimnim gasom u dimnom kanalu između grejača i elektrofiltra. Količina opreme je minimalna.
U postupku direktnog ubacivanja sorbenta u ložište suvi sorbent se ubrizgava u ložište u optimalnoj temperaturnoj regiji iznad plamena.

U postupku sa cirkulišućim fluidizovanim slojem suvi sorbent, najčešće $\mathrm{Ca}(\mathrm{OH})_{2}$, reaguje sa ovlaženim dimnim gasom koji se kreće naviše kroz suve sorbente do elektrofiltara. Deo zahvata se recirkuliše kako bi se povećalo iskorišćenje sorbenta. Dodatna korist ovog postupka je stalna abrazija čestica sorbenta koja dovodi do izlaganja svežim alkalima.

\section{Regenerativni tehnološki postupci odsumporavanja dimnih gasova}

$\mathrm{U}$ regenerativne tehnološke postupke za ODG spadaju četiri mokra regenerativna postupka u kojima azot suboksid, magnezijum oksid, natrijum karbonat ili amini reaguju sa dimnim gasom, i jedan suvi regenerativni postupak u kome se koristi aktivni ugalj. Proizvod ovih postupaka je tečni $\mathrm{SO}_{2}$. Regenerativni tehnološki postupci za ODG se koriste neznatno u svetu. Ovi postupci imaju komparativno visoke troškove u odnosu na ostale postupke ODG. Veliki problem ovih postupaka je prodaja nusproizvoda. Posledica toga je da su neka postrojenja koja su koristila regenerativne tehnološke postupke za ODG počela da koriste mokre krečnjačke postupke za ODG.

\section{Dosadašnja primena postupaka za odsumporavanje dimnih gasova}

Godine 1980. instalirana su postrojenja za ODG na termoelektrane ukupne snage oko 30.000 MW, a taj trend se nastavio sa oko 100.000 MW svakih deset godina [5]. Nije bilo značajnog povećanja kapaciteta postrojenja za ODG regenerativnim postupcima od početka osamdesetih godina prošlog veka. Kako mokri postupci za ODG do sada dominiraju, zanimljiva je analiza primene mokrih postupaka za ODG. Većina tehno- 
loških postupaka za ODG koji se primenjuju u svetu su mokri postupci sa krečnjakom i suvi postupak sa rasprši-vanjem. Kod mokrih tehnoloških postupaka za ODG koje ne koriste krečnjak koristi se kreč kao skuplji sorbent, ili je njihova primena ograničena dostupnošću sorbenta koji postupak zahteva. Suvi tehnološki postupci za ODG osim suvog postupka raspršivanjem nisu se našli u komercijalnoj upotrebi $u$ dovoljnoj meri, ili kod njih postoji problem ograničene upotrebe sorbenta.

Mokri tehnološki postupci za ODG dominiraju nad drugim postupcima usled visoke efikasnosti uklanjanja $\mathrm{SO}_{2}$ i ekonomske isplativosti, naročito mokri postupci koji se zasnivaju na krečnjaku. Gips kao nusproizvod čini mokre postupke za ODG atraktivnijim. Retka upotreba suvih postupaka za ODG posledica je većih cena reagenasa i ograničenja u pogledu odlaganja nusproizvoda.

Odsumporavanje sa krečnjakom ubrzanom oksidacijom je najrasprostranjeniji postupak u u svetu danas, i ovi sistemi čine oko jedne trećine mokrih sistema za uklanjanje $\mathrm{SO}_{2}$. Ubrzana oksidacija je postuapk koji se najčešće koristi stoga što smanjuje mogućnost oksidacije postrojenja za ODG, poboljšavanja mogućnost sušenja i daje nusproizvod koji se može koristiti za punjenje zemljišta ili za prodaju kao gips za poljoprivredu ili industriju cementa. Unapređena sposobnost sušenja dodatno smanjuje površinu prostora potrebnog za smeštaj otpada.

\section{PRAVNI ASPEKT \\ ODSUMPORAVANJA DIMNIH GASOVA U SRBIJI}

Regulativa koja se odnosi na zaštitu životne sredine, a naročito Direktiva 2010/75/EU Evropskog parlamenta i Saveta od 24. novembra 2010. o industrijskim emisijama (integrisana prevencija i zaštita zagađenja) [6] postavlja stroge uslove, tehničke zahteve i GVE za postrojenja u pogledu emisije $\mathrm{SO}_{2}$ na $200 \mathrm{mg} / \mathrm{m}^{3}$. Ovakvi propisi zahtevaju detaljnu analizu kvaliteta uglja, kao i pažljiv odabir tehnološkog postupka za odsumporavanje dimnih gasova i procenu troškova.

Jedan od osnovnih ciljeva Nacionalnog programa za zaštitu životne sredine Republike Srbije za period od 2005-2014. godine u energetskom sektoru je smanjenje emisije sumpornih oksida iz termoelektrana kao što su Termoelektrana "Kostolac B" i Termoelektrana "Nikola Tesla A" i "Nikola Tesla B". Do sada su u ovim termoelektranama ugrađeni samo elektrofiltri za uklanjanje čestica, ali nisu preduzete nikakve mere u cilju odsumporavanja dimnih gasova.

Kako su tehnološki postupci za ODG zasnovani na krečnjaku u svetu u najširoj upotrebi zbog visoke efikansosti, ekonomske opravdanosti i gipsa kao nusproizvoda, može se očekivati da će termoelektrane u Srbiji koristiti ovaj postupak. Dve kompanije - Mitsubishi i Hitachi predstavile su svoje tehnološke postupke za odsumporavanje dimnih gasova mokrim krečnjačkim posutpkom na Prvom simpozijumu "O odsumporavanju dimnih gasova” održanom na Paliću 2012. [7, 8].

Ministarstvo prosvete, nauke i tehnološkog razvoja Republike Srbije finansiralo je projekat "Razvoj tehnoloških procesa za dobijanje ekoloških materijala zasnovanih na nemetalnim mineralima", u okviru koga su vršena ispitivanja litotamnijskog krečnjaka iz ležišta "Dobrilovići" u blizini Loznice za upotrebu u neregenerativnim mokrim postupcima. Ova ispitivanja pokazala su da se ovaj krečnjak može koristiti za odsumporavanje dimnih gasova, kao i da se u tom postupku dobija gips zadovoljavajućeg kvaliteta kao nusproizvod [9]. 
U poslednje tri decenije troškovi postrojenja za uklanjanje $\mathrm{SO}_{2}$ u svetu su se smanjili za preko $30 \%$, te postoje proračuni da su troškovi odsumporavanja danas oko $100 \$ / \mathrm{kW}$ [10]. Postavljanje sistema na postojeća postrojenja povećava troškove do $30 \%$ zavisno od modifikacija postojeće opreme i uslova pod kojima postrojenja rade, kao što su protok i temperatura. Troškovi takođe rastu sa porastom sadržaja sumpora, budući da se ista količina gasa mora tretirati sa više reagensa. Krečnjak i kreč kao reagensi po sebi nisu skupi, ali upotreba aditiva ili reagenasa značajno povećava troškove. $\mathrm{Na}$ troškove utiče i trošak odlaganja otpada, cena nusproizvoda, kao i gubitak energije koja je potrebna za postupak i drugi fiksni i varijabilni troškovi [5]. Efikasnost kontrole emisija kod krečnjačkih sistema je ograničena na oko $90 \%$, dok je kontrola efikasnosti kreča do $95 \%$, ali je značajno skuplja.

\section{PROCENA TROŠKOVA ODSUMPORAVANJA DIMNIH GASOVA}

Kontinualno merenje emisije ne daje dovoljno precizne podatke za projektovanje postrojenja za ODG, tako da se dodatne informacije moraju pribaviti na osnovu analize uglja i podataka o postojećem ložištu koji se pojedinačno mere [11]. Analizom uglja dobijaju se ključni podaci za projektovanje postrojenja za odsumporavanje dimnih gasova - referentni kvalitet uglja, analiza dimnih gasova na ulazu u postrojenje, kao i opseg koncentracija $\mathrm{SO}_{2} \mathrm{u}$ dimnim gasovima [12].

Postupak odsumporavanja dimnih gasova ne zahteva samo sistem za dimni gas i apsorber, već i povezane sisteme za pripremu sorbenta i odlaganje nusproizvoda. Osnovni parametri koji se koriste za projektovanje sistema za ODG su radni parametri termoelektrane (kao što je snaga bloka, specifična potrošnja toplote, višak vazduha, temteratura dimnog gasa), karakteristike dimnog gasa (zapreminski protok, vlaga, koncentracija hlorida i fluorida, sadržaj čestica i $\mathrm{SO}_{2}$, dozvoljeni sadržaj čestica u emitovanom dimnom gasu), zahtevani kvalitet nusproizvoda. Tehnička i ekonomska analiza mogućnosti primene postupka odsumporavanja dimnih gasova u termoelektranama u Srbiji pokazala je da je mokri krečnjački postupak ubrzanom oksidacijom najbolje rešenje.

Dodatni činioci koje treba razmotriti pri proceni troškova odsumporavanja dimnih gasova su prostor oko termoelektrane, investicije, vreme na koje je potrebno zaustaviti termoelektranu tokom instalacije sistema za ODG, plan rada termoelektarne tokom godine.

Gips kao nusproizvod postupka odsumporavanja zahteva deponovanje na bezbednoj deponiji na koju se ne deponuje biorazgradivi otpad, a deponija mora da ispuni neophodne zahteve u cilju sprečavanja zagađenja tla, vazduha i površinskih voda kombinacijom geoloških barijera i neprobojnih slojeva [13].

\section{ZAKLJUČAK}

Sagorevanjem uglja u postrojenjima za proizvodnju električne energije emituje se najveći deo sumpor dioksida u Srbiji. Propisi u oblasti zaštite životne sredine usvojeni u Srbiji u protekloj deceniji zahtevaju postepeno uvođenje tehnoloških postupaka za tretman dimnih gasova, a jedan od osnovnih ciljeva Nacionalnog programa za zaštitu životne sredine Republike Srbije za period od 2005-2014. godine u energetskom sektoru je smanjenje emisije sumpornih oksida iz termoelektrana. Do sada u termoelektranama nisu preduzete nikakve mere u cilju odsumporavanja dimnih gasova. Kako tehnološki postupci za ODG 
zasnovani na krečnjaku dominiraju u svetu zbog visoke efikasnosti, ekonomske opravdanosti i gipsa kao nusproizvoda, može se očekivati da će termoelektrane u Srbiji koristiti ovaj postupak. Tehnička i ekonomska analiza mogućnosti primene postupka odsumporavanja dimnih gasova u termoelektranama u Srbiji pokazale su da je „mokri“ krečnjački postupak ubrzanom oksidacijom najbolje rešenje.

Sektor za prevenciju i kontrolu aerozagađenja Nacionalne istraživačke laboratorije za upravljanje rizikom SAD objavio je model za izračunavanje troškova zaštite životne sredine za termoelektrane (Coal Utility Environmental Cost Workbook, CUECost) [14]. Pomoću njega je moguće napraviti grubu kalkulaciju troškova (sa preciznošću od $\pm 30 \%$ ) za termoelektrane snage između 100 i 2000 MW u slučaju primene mokrog krečnjačkog postupka ubrzanom oksidacijom, a koja se zasniva na projektu i ekonomskim kriterijumima po odluci korisnika. CUECost algoritmi predstavljaju polaznu osnovu za izračunavanje troškova odsumporavanja dimnih gasova mokrim krečnjačkim postupkom ubrzanom oksidacijom koji mogu biti dobra polazna osnova i za procenu troškova ODG termoelektrana u Srbiji.

\section{LITERATURA}

[1] Uredba o graničnim vrednostima emisija zagađujućih materija u vazduh, Službeni glasnik RS 71/201 i 6/2011.

[2] http://kgh.kvartetv.com/fajlovi/ 37.\%20kongres/37-38.pdf

[3] Mitrović D., Kostović N., Milovanović Đ., Specifičnosti projektovanja postrojenja za odsumporavanje dimnih gasova na postojećim termoelektranama na lignit u Srbiji, Zbornik radova Prvog simpozijuma Odsumporavanje dimnih gasova", Privredna komora Srbije, (2012) 12-19.

[4] Keeth RJ, Ireland PA, and Radcliffe PT, Economic Evaluations of 28 FGD Processes, in Proceedings of the 1991 $\mathrm{SO}_{2}$ Control Symposium Palo Alto, CA, Electric Power Research Institute, 1991, 273-2-90.

[5] http://www.iea-coal.org.uk/site/2010/ database-section/coalpower?LanguageId $=0$

[6] http://eur-lex.europa.eu/LexUriServ/ LexUriServ.do?uri=OJ:L:2010:334:00 17:0119:en:PDF

[7] Okamoto T., Nagayasu T., Tanaka N., Mitsubiši tehnologija mokrim postupkom odsumporavanja dimnih gasova, Zbornik radova Prvog simpozijuma „Odsumporavanje dimnih gasova“, Privredna komora Srbije, Beograd, 2012, 60-71.

[8] Taguchi Y., Vollmer B., Tehnologija firme Hitachi za odsumporavanje dimnih gasova, Zbornik radova Prvog simpozijuma ,Odsumporavanje dimnih gasova“, Privredna komora Srbije, Beograd, 2012, 27-34.

[9] Sekulić Ž., Jovanović V., Kašić V., Litotamnijski krečnjak ležišta "Dobrilovići“ u odsumporavanju dimnih gasova mokrim postupkom, Rudarski radovi, 3 (2012) 41-48.

[10] Smith D., Cost of $\mathrm{SO}_{2}$ scrubbers down to $\$ 100 / \mathrm{kW}$, Power Engineering, 105 (2001) 63-66.

[11] Thomsen R., Dickamp M., Kriterijumi za projektovanja postrojenja za odsumporavanje dimnih gasova, Zbornik radova Prvog simpozijuma "Odsumporavanje dimnih gasova”, Privredna komora Srbije, (2012) 20-26.

[12] Stojiljković D., Životić D., Milovanović D., Jovović A., Manić N., Jova- 
nović V., Značaj definisanja referentnih karakteristika uglja za projektovanje sistema za ODG, Zbornik radova Prvog simpozijuma "Odsumporavanje dimnih gasova", Privredna komora Srbije, (2012) 2-11.

[13] Vlajić D., Simović I., Kostović N., Stanković M., Deponije suspenzije gipsa iz procesa odsumporavanja bloka TE Kostolac B3, Zbornik radova Prvog simpozijuma "Odsumporavanje dimnih gasova”, Privredna komora Srbije, (2012) 155-162.

[14] http://www.epa.gov/ttncatc1/ products.html\#cccinfo 